\title{
PENGARUH ORGANISATIONAL CITIZENSHIP BEHAVIOR (OCB) TERHADAP KINERJA DOSEN UNIVERSITAS SULAWESI BARAT
}

\section{INFLUENCE ORGANISATIONAL CITIZENSHIP BEHAVIOR (OCB) TO LECTURER PERFORMANCE OF WEST SULAWESI UNIVERSITY}

Magfirah dan Wahyu Maulid Adha

Fakultas Ekonomi Universitas Sulawesi Barat

Economi Faculty West Sulawesi University

\begin{abstract}
Abstrak
Penelitian ini bertujuan untuk mengetahui pengaruh Organizational Citizenship Behavior (OCB) terhadap kinerja dosen Universitas Sulawesi Barat dengan beberapa indikator yaitu altuisme, conscientiousness, civic virtue, sportsmanship dan courtesies. Penelitian ini dilaksanakan di Universitas Sulawesi Barat. Populasi penelitian adalah seluruh dosen Universitas Sulawesi Barat, baik dosen tetap maupun dosen luar biasa. Sampel dipilih secara total. Pengumpulan data dilakukan dengan tekhnik observasi, wawancara, dan kuesioner. Data dianalisis dengan persentase dan regresi linear. Hasil yang diharapkan bahwa Organizational Citizenship Behavior (OCB) berpengaruh secara signifkan terhadap kinerja dosen Universitas Sulawesi Barat.
\end{abstract}

Keyword : Organizational Citizenship Behavior (OCB) Altruisme, conscientiousness, civic virtue, sportsmanship dan courtesies, Kinerja dosen

\section{Abstract}

This Research Is Meant To Know The Influence Of Ocb To Lecturer Of West Sulawesi University With A Few Indicator Which Is, Altuisme, Consciencetiousness, Civic Virtue, Sportmanship, And Courtesies. This Research Is Being Held At West Sulawesi University. The Researcher Of This Research Are All Of The Teacher In West Sulawesi University. The Sample Is Being Choose By Total. Collecting The Data Is Using A Technic Of Observation, Interview, And Cuesioner. The Data Is Analyse With Percentage And Linear Regretion. The Expected Result Of Ocb Influence Significanly To Lecturer Performance Of West Sulawesi University.

Keyword

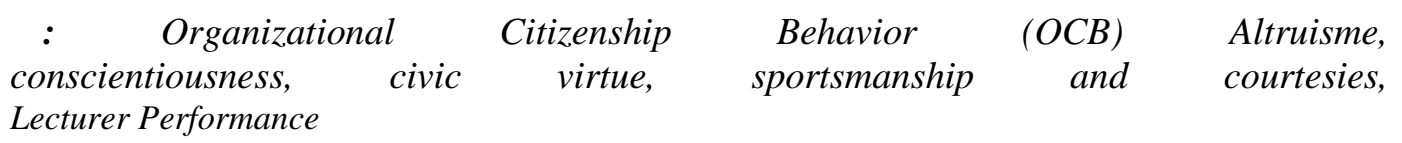




\section{PENDAHULUAN}

Sebagai makhluk sosial, manusia mempunyai kemampuan untuk memiliki empati kepada orang lain dan lingkungannya dan menyelaraskan nilai-nilai yang dianutnya. Dengan nilai-nilai yang dimiliki lingkungannya untuk menjaga dan meningkatkan interaksi sosial yang lebih baik.. OCB merupakan tindakan seseorang di luar kewajibannya, tidak memperhatikan kepentingan diri sendiri (Sloat, 1999), tidak membutuhkan deskripsi pekerjaan (job description) dan sistem imbalan formal, bersifat sukarela dalam bekerjasama dengan teman sekerja dan menerima perintah secara khusus tanpa keluhan (Organ dan Konovski, 1989).

Organ mengidentifikasikan bahwa
perilaku kerja karyawan ( OCB)
berhubungan dengan kepuasan kerja. Menurut Organ (1988), OCB terdiri dari lima dimensi: (1) altruism, yaitu perilaku membant umeringankan pekerjaan yang ditujukan kepada individu dalam suatu organisasi, (2) courtesy, yaitu membantu teman kerja mencegah timbulnya masalah sehubungan dengan pekerjannya dengan cara ber konsultasi dan informasi serta menghargai kebutuhan mereka, (3) sportsmanship, yaitu toleransi pada situasi yang kurang ideal di tempat kerja tanpa mengeluh, (4) civic virtue, yaitu terlibat dalam kegiatan -kegiatan organisasi dan peduli pada kelangsungan hidup organisasi, (5) conscientiousness, yaitu melakukan hal-hal yang menguntungkan organisasi - seperti mematuhi peraturan peraturan di organisasi

Perilaku Organizationl Citizenship Behavior sudah tertanam sejak Universitas Sulawesi Barat ini masih dalam bentuk yayasan (Swasta). Oleh sebab itu masalah yang berkaitan dengan Organizational Citizenship Behavior (OCB)terhadap kinerja dosen Universitas Sulawesi Barat masih actual dibicarakan sehingga menarik untuk dikaji secara mendalam melalui penelitian ini .Atas dasar tersebut, maka penelitian ini diarahkan untuk mengetahui pengaruh Organizational Citizenship Behavior terhadap kinerja dosen.

Pertimbangan lain yang muncul adalah adanya karyawan yang tidak memiliki ikatan apapun pada Universitas Sulawesi Barat, tetapi justru memberikan kontribusi yang jauh lebih bagus ketimbang dengan karyawan yang diikat secara formal. Kondisi ini tentunya akan berdampak negative terhadap karyawan secara keseluruhan dan apabila hal ini terus dibiarkan maka citra Universitas Sulawesi Barat dimata masyarakat akan memberikan penilaian yang buruk.

Berdasarkan dari uraian diatas, maka permasalahan yang diajukan dalam penelitian ini adalah : "Bagaimana Organizational Citizenship Behavior berpengaruh terhadap Kinerja Dosen Universitas Sulawesi Barat?"

\section{Metode Penelitian}

Tempat Penelitian ini dilaksanakan pada Universitas Sulawesi Barat yang bertempat di Kabupaten Majene Provinsi Sulawesi Barat. Pemilihan lokasi dimaksudkan untuk melihat pengaruh Organization Citizen Behavior (OCB) terhadap kinerja dosen.

Pendekatan yang digunakan dalam penelitian ini adalah studi kasus dengan desain kualitatif deskriptif dan analisis regresi sederhana. Analisis kualitatif deskriptif digunanakan untuk menjelaskan penyebab permasalahan, uraian-uraian, penjelasan table dan prosentase. Sedangkan analisis regresi linear sederhana untuk mengetahui pengaruh OCB terhadap kinerja dosen Universitas Sulawesi Barat.

Metode pengumpulan data yang digunakan dalam penelitian ini adalah :

1. Kuisioner, yaitu suatu metode pengumpulan data yang sifatnya 
terstruktur dengan cara mengedarkan daftar pertanyaan yang sama yang mewakili suatu kajian dalam penelitian, dimana pengumpul data telah menyiapkan instrument penelitian berupa pertanyaan-pertanyaan tertulis yang alternatif jawabannya pun telah disiapkan. Untuk melihat perbandingan jawaban dari para responden terhadap suatu permasaalahan yang akan dikaji.

2. Wawancara mendalam (Indepth Interview), merupakan teknik wawancara yang sifatnya lebih bebas untuk menemukan permasaalahan secara lebih terbuka dan mendalam, dimana pihak yang diwawancarai diminta pendapat dan ide-idenya.

Populasi dalam penelitian ini adalah seluruh dosen pada Universitas Sulawesi Barat yang tersebar dibeberapa fakultas yaitu Fakultas Pertanian, Fakultas Mipa, Fakultas Ekonomi, Fakultas Teknik, Fakultas Ilmu Sosial dan Politik, Fakultas Hukum, Fakultas Sastra dan Fakultas Ilmu Kesehatan. Sampel diambil dengan menggunakan metode Slovin dengan tingkat kesalahan yang dikehendaki $5 \%$ atau 0,05 dengan rumus sebagai berikut:

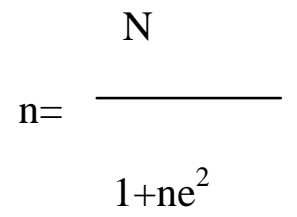

Dimana :

$\mathrm{n}=$ Jumlah Sampel

$\mathrm{N}=$ Jumlah Populasi

tolerance)

e $=$ Batas Toleransi Kesalahan (error

Jumlah populasi dalam penelitian ini adalah sebanyak 103 orang, sedangkan jumlah sampel nya adalah : $103 /\left(1+103 \times 0,05^{2}\right)=$ 81,90 dibulatkan menjadi 82 orang.
Data dikumpulkan dan diolah terlebih dahulu agar dapat disajikan secara sistematis dan jelas dengan menggunakan :

1. Analisis Kualitatif Deskriptif Analisis kualitatif deskriptif yang digunakan untuk penjelasan penyebab permasalahan diatas dengan uraianuraian, penjelasan table dan prosentase. Analisis kualitatif deskriptif ini digunakan untuk menguji hipotesis pertama.

2. Analisis Regrasi Liner berganda Teknik analisis data untuk penelitian ini adalah Analisis Regresi Berganda (Multiple Regression Analysis), dengan menggunakan aplikasi SPSS 16.00 .

Dengan rumus :

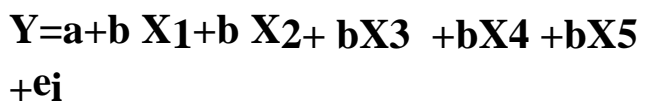

Keterangan: Y
OrganizationCitizenshipBehavior(
OCB)

a :Intersep

b :KoefisienRegresi

$\mathrm{X} 1$ :Altruisme

$\mathrm{X}_{2}$ :Conscientiousness

X3:Civic Virtue

X4:Sportsmanship

X5:Courtesy

e :Standarerror

\section{Hasil dan Pembahasan}

A. Sumberdaya Manusia Universitas Sulawesi Barat. 
Kondisi Sumberdaya manusia dalam hal ini tenaga pendidik/dosen Universitas Sulawesi Barat sebanyak 103 orang namun yang menjadi sampel dalam penelitian ini adalah 82 orang .

Tolok Ukur Kinerja Dosen Universitas Sulawesi Barat

Hasil kerja seorang dosen atau yang biasa disebut kinerja dapat dilihat dari jika

seorang dosen tidaklah hanya harus memiliki dan menggunakan kecerdasan intelektualnya saja melainkan aspek kecerdasan emosional dan spiritual juga harus dimiliki dan digunakan seorang dosen. Ketiga kecerdasan tersebut merupakan kemampuan yang harus dimiliki oleh dosen dalam memberikan makna dari setiap masalah yang dihadapi, sehingga seorang dosen mampu membangkitkan kepuasan dan motivasi bagi diri mahasiswa dalam belajar di kelas dan meraih prestasi belajar yang baik.

Kinerja dosen tidak hanya membutuhkan kemampuan intelektualnya, tetapi dalam menyelesaikan masalah tersebut kemampuan emosi atau kecerdasan emosi juga diperlukan. Pada dasarnya para dosen membutuhkan kecerdasan emosi yang tinggi karena dalam hal belajar mengajar dosen berinteraksi dengan banyak orang, dalam hal ini mahasiswa, baik dalam membentuk moral maupun disiplin. Kecerdasan emosional dosen berpengaruh positif terhadap motivasi belajar mahasiswa, jika kecerdasan emosional seorang dosen meningkat, maka motivasi belajar mengajar mahasiswa juga meningkat.

B. Hasil Penelitian

Penelitian ini menggunakan kuesioner kepada responden yang sasarannya ditujukan kepada dosen Universitas
Sulawesi Barat dengan penentuan sampel menggunakan metode slovin.

Berdasarkan hasil penelitian pada Universitas Sulawesi Barat, sebagaimana pada table yang dapat dianalisa dalam pembahasan ini sebagai berikut :

C. Pembahasan dan Analisa Tentang Pengaruh Organizational Citizenship Behavior Terhadap Kinerja Dosen Universitas Sulawesi Barat.

Dalam menilai kinerja Sumber daya Manusia dalam hal ini dosen Universitas Sulawesi Barat, dalam penelitian ini ada satu variable terikat Y) dan lima variable bebas(X)

Untuk mempertajam analisa, dilakukan dengan analisis regresi linier berganda. Variabel dependen dalam analisa ini adalah kinerja dosen (Y). sedangkan variable independen adalah Organization Citizhen Behavior yang indikatornya adalah $\mathrm{X} 1=$ altruism, $\mathrm{X} 2=$ conscientiousness, $\mathrm{X} 3=$ civic virtue, $\mathrm{X} 4=$ cortesy dan $\mathrm{X}=$ sportsmanship. Oleh sebab itu maka hubungan variable dependen dan independen digambarkan sebagai berikut:

Jika (Y) adalah variable dependen dan variable ini tergantung dari 5 buah varabel dependen yaitu $X 1, X 2, X 3$, $\mathrm{X} 4, \mathrm{X} 5$ maka fungsinya adalah $\mathrm{Y}=\mathrm{f}$ (X1, X2, X3, X4, X5, e)

Analisa Regresi Linear Berganda diperoleh persamaan:

$\mathrm{Y}=\mathrm{a}+\mathrm{b} 1 \mathrm{X} 1, \mathrm{~b} 2 \mathrm{X} 2, \mathrm{~b} 3 \mathrm{X} 3, \mathrm{~b} 4 \mathrm{X} 4, \mathrm{~b} 5 \mathrm{X} 5$

$+\mathrm{e}$

Analisa Data

Hasil tabulasi jawaban responden atas factor altruism, conscientiousness, civic virtue, cortesy dan sportsmanship diukur berdasarkan skor jawaban $(5=$ sangat setuju, $4=$ setuju, $3=$ ragu-ragu, $2=$ tidak setuju dan $1=$ sangat tidak setuju) 
Tabel 1

Coefficients $^{\mathrm{a}}$

\begin{tabular}{|l|r|r|r|r|r|}
\hline \multirow{2}{*}{ Model } & \multicolumn{2}{|c|}{$\begin{array}{l}\text { Unstandardized } \\
\text { Coefficients }\end{array}$} & \multicolumn{1}{|c|}{$\begin{array}{c}\text { Standardized } \\
\text { Coefficients }\end{array}$} & & \\
\cline { 2 - 5 } & \multicolumn{1}{|c|}{$\mathrm{B}$} & Std. Error & \multicolumn{1}{c|}{ Beta } & \multicolumn{1}{c|}{$\mathrm{t}$} & \multicolumn{1}{c|}{ Sig. } \\
\hline 1 (Constant) & 15.493 & 5.492 & & 2.821 & .006 \\
Altruisme & .274 & .082 & .358 & 3.335 & .001 \\
Conscientousness & .152 & .148 & .111 & 1.026 & .308 \\
Civic Virtue & -.054 & .094 & -.062 & -.572 & .569 \\
Sportmanship & -.008 & .068 & -.013 & -.120 & .905 \\
Courtesy & -.024 & .116 & -.023 & -.208 & .835 \\
\hline
\end{tabular}

a. Dependent Variable: Kinerja

Sumber : Output program SPSS 17.0

\section{Analisis Regrasi Linear Berganda}

Dapat ditentukan persamaan regresinya berdasarkan kolom B yang merupakan koefisien regresi tiap variabelnya. Jadi persamaan regresinya adalah sebagai berikut :

$\mathrm{Y}=15,493+0,274 \mathrm{X} 1+0,152 \mathrm{X} 2-$ 0,054 X3 - 0,008 X4-0,024 X5

Persamaan regresi di atas dapat di jelaskan sebagai berikut :

a. Konstanta 15,493 artinya bila X1, X2, $\mathrm{X} 3, \mathrm{X} 4$ dan $\mathrm{X} 5$ nilainya 0 maka nilai kinerja adalah 15,493 .

b. Koefisien regresi variable X1 sebesar 0,274 artinya apabila X1 dinaikkan 1 satuan maka nilai kinerja akan mengalami peningkatan sebesar 0,274 dengan asumsi variable independen lain nilainya tetap.

c. Koefisien regrasi variable X2 sebesar 0,152 artinya apabila X2 dinaikkan 1 satuan maka nilai kinerja akan mengalami peningkatan sebesar 0,152 dengan asumsi variable independen lainnya tetap.

d. Koefisien regrasi variable X3 sebesar 0,54 artinya bila X3 dinaikkan 1 satuan maka nilai kinerja akan mengalami penurunan sebesar 0,54 dengan asumsi variable independen lain nilainya tetap.

e. Koefisien regresi variable $\mathrm{X} 4$ sebesar 0,008 artinya bila $\mathrm{X} 4$ dinaikkan 1 satuan maka nilai kinerja akan mengalami penurunan sebesar 0,008 dengan asumsi variable independen lainnya tetap.

f. Koefisien regresi variable X5 ebesar 0,024 artinya bila X5 dinaikkan 1 satuan maka nilai kinerja akan mengalami penurunan sebesar 0,024 dengan asumsi variable independen lainnya tetap. 
Tabel 2

Model Summary ${ }^{b}$

\begin{tabular}{|l|r|r|r|r|r|}
\hline Model & \multicolumn{1}{|c|}{$\mathrm{R}$} & R Square & \multicolumn{1}{c|}{$\begin{array}{c}\text { Adjusted R } \\
\text { Square }\end{array}$} & $\begin{array}{c}\text { Std. Error of } \\
\text { the Estimate }\end{array}$ & Durbin-Watson \\
\hline 1 & $.373^{\mathrm{a}}$ & .139 & .083 & .830 & 2.241 \\
\hline
\end{tabular}

a. Predictors: (Constant), Courtesy, Conscientousness, Civic Virtue, Altruisme, Sportmanship

b. Dependent Variable: Kinerja

Tabel 3

Uji f

ANOVA $^{b}$

\begin{tabular}{|c|c|c|c|c|c|c|}
\hline \multicolumn{2}{|c|}{ Model } & Sum of Squares & $\mathrm{df}$ & Mean Square & $\mathrm{F}$ & Sig. \\
\hline \multirow[t]{3}{*}{1} & Regression & 8.475 & 5 & 1.695 & 2.458 & $.040^{\circ}$ \\
\hline & Residual & 52.403 & 76 & .690 & & \\
\hline & Total & 60.878 & 81 & & & \\
\hline
\end{tabular}

a. Predictors: (Constant), Courtesy, Conscientousness, Civic Virtue, Altruisme, Sportmanship

b. Dependent Variable: Kinerja

\section{Koefisien Determinasi}

Berdasarkan output Tabel 2, diperoleh nilai $\mathrm{R}$ square sebesar 0,139 atau $13,9 \%$, artinya semua variabel independen memiliki pengaruh sebesar 13,9 terhadap variabel dependen. Sisanya sebesar $86,1 \%$ dipengaruhi oleh variabel lain.

1. Pengujian koefisien regresi variable X1 (Altruism) terhadap Y (kinerja)

Langkah-langkah untuk melakukan uji t untuk variable $\mathrm{X} 1$ sebagai berikut:

a. Hipotesis 
Ho = Altruism (X1) secara parsial tidak mempunyai pengaruh yang signifikan terhadap kinerja $(\mathrm{Y})$ $\mathrm{Ha}=$ Altruism (X1) secara parsial mempunyai pengaruh yang signifikan terhadap kinerja (Y)

b. Tingkat Signifikansi

Tingkat signifikansi yang digunakan adalah 0,05 (alpha = 5\%). Berdasarkan table diatas signifikansi variable altruism (X1) sebesar 0,001. Artinya tingkat signifikansi variable kinerja (Y) lebih kecil dari standar signifikansi, sehingga dapat dikatakan bahwa Ha diterima.

c. Menentukan t hitung Menentukan t hitung dari table 37 berdasarkan table diatas, maka $\mathrm{t}$ hitung variable $\mathrm{X} 1$ sebesar 3,335.

d. Menentukan t table

Tabel distribusi t dicari pada $\alpha=$ $5 \%: 2=2,5 \%$ (uji 2 sisi) dengan derajat kebebasan $(\mathrm{df})=\mathrm{n}-\mathrm{k}-1$ atau $82-5-1=76$. Dengan pengujian 2 sisi (signifikansi = $0,025)$ hasil diperoleh untuk t table sebesar 1,992.

e. Kriteria pengujian

Ho diterima jika - $\mathrm{t}$ table $\leq$ hitung $\leq$ $\mathrm{t}$ table

Ho ditolak jika $\mathrm{n}-\mathrm{t}$ hitung $\leq$ table atau t hitung $>\mathrm{t}$ table

f. Membandingkan thitung dengan $t$ table

Nilai $\mathrm{t}$ hitung > t table $(3,335>$ 1,992

Berdasarkan hasil output yang dilihat dari nilai signifikansi, nilai yang diperoleh adalah 0.00 atau $0 \%$. Jadi dapat disimpilkan bahwa variable $\mathrm{X} 1$ memiliki pengaruh yang sangat signifikan, hal tersebut diperkuat karena tingkat signifikansi yang diperoleh lebih kecil dari standar yang digunakan yakni $0 \%$ dari $5 \%$. Selain dari nilai signifikansi, dapat dilihat juga dari perbandingan nilai $\mathrm{t}$ hitung dan $\mathrm{t}$ table. Berdasarkan hasil output diperoleh nilai sebesar 3,335 sedangkan nilai $\mathrm{t}$ table diperoleh sebesar 1,992. Berdasarkan perbandingan tersebut, diperoleh kesimpulan bahwa hipotesis yang menyatakan variable altruism (X1) memiliki pengaruh terhadap kinerja dapat diterima.

2. Pengujian Koefisien regresi variable Conscientousness

Langkah-langkah untuk melakukan uji $\mathrm{t}$ untuk variable likuiditas sebagai berikut :

a. Hipotesis

Ho $=$ Conscientiousness secara parsial tidak mempunyai pengaruh yang signifikan terhadap kinerja

$\mathrm{Ha}=$ Conscientiousness secara parsial mempunyai pengaruh yang signifikan terhadap kinerja.

b. Tingkat signifikansi

Tingkat signifikansi yang digunakan adalah $0,05(\alpha=5 \%)$ berdasarkan table 37 signifikansi variable conscientiousness (X2) sebesar 0,308. Artinya tingkat signifikansi variable X2 lebih besar dari standar signifikansi sehingga dapat dikatakan bahwa Ha ditolak.

c. Menentukan t hitung

Menentukan $t$ hitung dari table 37 berdasarkan table diatas, maka $\mathrm{t}$ hitung variable X2 sebesar 0,572

d. Menentukan t table

Tabel distribusi $\mathrm{t}$ dicari pada $\alpha=$ $5 \%: 2=2,5 \%$ (uji 2 sisi) dengan derajat kebebasan $(\mathrm{df})=\mathrm{n}-\mathrm{k}-1$ atau $82-5-1=76$. Dengan pengujian 2 sisi (signifikansi = $0,025)$ hasil diperoleh untuk t table sebesar 1,992.

e. Kriteria pengujian

Ho diterima jika $-\mathrm{t}$ table $\leq \mathrm{t}$ hitung $\leq \mathrm{t}$ table

Ho ditolak jika $-\mathrm{t}$ hitung $<-\mathrm{t}$ table atau $t$ hitung $>\mathrm{t}$ table 
f. Membandingkan t hitung dengan $t$ table

Nilai $\mathrm{t}$ hitung $<\mathrm{t}$ table $(1,026<$ 1,992)

Berdasarkan pengujian statistic diatas dengan menggunakan uji $\mathrm{t}$ diperoleh tingkat signifikansi lebih besar dari standar signifikansi yang ditetapkan yaitu 0,05 atau $5 \%$ dan perbandingan antara $\mathrm{t}$ hitung dan $\mathrm{t}$ table dimana $t$ hitung sebesar 1,026 lebih kecil dari t table yakni 1,992 dapat disimpulkan bahwa $\mathrm{Ha}$ ditolak. Artinya bahwa secara parsial variable X2 tidak memiliki pengaruh yang signifikan terhadap vaiabel Kinerja (Y).

3. Pengujian koefisien regresi variable Civic Virtue

Langkah-langkah untuk melakukan uji $\mathrm{t}$ untuk variable civic virtue (X3) sebagai berikut:

a. Hipotesis

Ho = Civic virtue secara parsial tidak mempunyai pengaruh yang signifikan terhadap kinerja.

$\mathrm{Ha}=$ Civic virtue secara parsial mempunyai pengaruh yang signifikan terhadap kinerja.

b. Tingkat signifikansi

c. Tingkat signifikansi yang digunakan adalah $0,05(\alpha=5 \%)$. Berdasarkan table 4.34 signifikansi variable civic virtue (X3) sebesar 0,569. Artinya bahwa tingkat signifikansi variable X3 lebih besar dari standar signifikansi sehingga dapat dikatakan bahwa Ha ditolak.

d. Menentukan t hitung

Menentukan $\mathrm{t}$ hitung dari table 4.34 berdasarkan table diatas, maka t hitung variable $\mathrm{X} 3$ sebesar 0,572

e. Menentukan t table

Tabel distribusi t dicari pada $\alpha=$ $5 \%: 2=2,5 \%$ (uji 2 sisi) dengan derajat kebebasan $(\mathrm{df})=\mathrm{n}-\mathrm{k}-1$ atau $82-5-1=76$. Dengan pengujian 2 sisi (signifikansi = 0,025 ) hasil diperoleh untuk $t$ table sebesar 1,992.

f. Kriteria pengujian

Ho diterima jika $-\mathrm{t}$ table $\leq \mathrm{t}$ hitung $\leq \mathrm{t}$ table

Ho ditolak jika -t hitung < -t table atau $t$ hitung $>t$ table

g. Membandingkan $t$ hitung dengan $t$ table

Nilai $\mathrm{t}$ hitung $<\mathrm{t}$ table $(0,572<$ 1,992)

Berdasarkan pengujian statistic diatas dengan menggunakan uji $t$ diperoleh tingkat signifikansi lebih besar dari standar signifikansi yang ditetapkan yaitu 0,05 atau $5 \%$ dan perbandingan antara $t$ hitung dan $t$ table dimana $t$ hitung sebesar 0,572 lebih kecil dari t table yakni 1,992 dapat disimpulkan bahwa $\mathrm{Ha}$ ditolak. Artinya bahwa secara parsial variable X3 tidak memiliki pengaruh yang signifikan terhadap vaiabel Kinerja (Y).

4. Pengujian koefisien regresi variable Sportmanship

Langkah-langkah untuk melakukan uji $\mathrm{t}$ untuk variable Sportmanship (X4) sebagai berikut:

a. Hipotesis

Ho = Sportmanship secara parsial tidak mempunyai pengaruh yang signifikan terhadap kinerja.

$\mathrm{Ha}=$ Sportmanship secara parsial mempunyai pengaruh yang signifikan terhadap kinerja.

b. Tingkat signifikansi

c. Tingkat signifikansi yang digunakan adalah $0,05(\alpha=5 \%)$. Berdasarkan table 4.34 signifikansi variable Sportmanship (X4) sebesar 0,905. Artinya bahwa tingkat signifikansi variable $\mathrm{X} 4$ lebih besar dari standar signifikansi sehingga dapat dikatakan bahwa Ha ditolak.

d. Menentukan t hitung 
Menentukan $\mathrm{t}$ hitung dari table 4.34 berdasarkan table diatas, maka t hitung variable $\mathrm{X} 3$ sebesar 0,120

e. Menentukan t table

Tabel distribusi t dicari pada $\alpha=$ $5 \%: 2=2,5 \%$ (uji 2 sisi) dengan derajat kebebasan $(\mathrm{df})=\mathrm{n}-\mathrm{k}-1$ atau $82-5-1=76$. Dengan pengujian 2 sisi (signifikansi = 0,025 ) hasil diperoleh untuk t table sebesar 1,992.

f. Kriteria pengujian

Ho diterima jika $-\mathrm{t}$ table $\leq \mathrm{t}$ hitung $\leq \mathrm{t}$ table

Ho ditolak jika $-\mathrm{t}$ hitung $<-\mathrm{t}$ table atau t hitung $>\mathrm{t}$ table

g. Membandingkan $t$ hitung dengan $t$ table

Nilai $\mathrm{t}$ hitung $<\mathrm{t}$ table $(0,905<$ 1,992)

Berdasarkan pengujian statistic diatas dengan menggunakan uji $\mathrm{t}$ diperoleh tingkat signifikansi lebih besar dari standar signifikansi yang ditetapkan yaitu 0,05 atau $5 \%$ dan perbandingan antara $\mathrm{t}$ hitung dan $\mathrm{t}$ table dimana t hitung sebesar 0,120 lebih kecil dari t table yakni 1,992 dapat disimpulkan bahwa $\mathrm{Ha}$ ditolak. Artinya bahwa secara parsial variable X4 tidak memiliki pengaruh yang signifikan terhadap vaiabel Kinerja (Y).

5. Pengujian koefisien regresi variable Courtesy.

Langkah-langkah untuk melakukan uji t untuk variable courtesy (X5) sebagai berikut:

a. Hipotesis

Ho $=$ courtesy secara parsial tidak mempunyai pengaruh yang signifikan terhadap kinerja.

$\mathrm{Ha}=$ courtesy secara parsial mempunyai pengaruh yang signifikan terhadap kinerja.

b. Tingkat signifikansi c. Tingkat signifikansi yang digunakan adalah $0,05(\alpha=5 \%)$. Berdasarkan table 4.34 signifikansi variable courtesy (X5) sebesar 0,835 Artinya bahwa tingkat signifikansi variable X5 lebih besar dari standar signifikansi sehingga dapat dikatakan bahwa Ha ditolak.

d. Menentukan t hitung

Menentukan $t$ hitung dari table 4.34 berdasarkan table diatas, maka t hitung variable X5 sebesar 0,208

e. Menentukan $t$ table

Tabel distribusi $\mathrm{t}$ dicari pada $\alpha=$ $5 \%: 2=2,5 \%$ (uji 2 sisi) dengan derajat kebebasan $(\mathrm{df})=\mathrm{n}-\mathrm{k}-1$ atau $82-5-1=76$. Dengan pengujian 2 sisi (signifikansi = $0,025)$ hasil diperoleh untuk t table sebesar 1,992.

f. Kriteria pengujian

Ho diterima jika $-\mathrm{t}$ table $\leq \mathrm{t}$ hitung $\leq \mathrm{t}$ table

Ho ditolak jika $-t$ hitung $<-t$ table atau $\mathrm{t}$ hitung $>\mathrm{t}$ table

g. Membandingkan $t$ hitung dengan $t$ table

Nilai $\mathrm{t}$ hitung $<\mathrm{t}$ table $(0,905<$ 1,992)

Berdasarkan pengujian statistic diatas dengan menggunakan uji $\mathrm{t}$ diperoleh tingkat signifikansi lebih besar dari standar signifikansi yang ditetapkan yaitu 0,05 atau $5 \%$ dan perbandingan antara $\mathrm{t}$ hitung dan $\mathrm{t}$ table dimana t hitung sebesar 0,208 lebih kecil dari t table yakni 1,992 dapat disimpulkan bahwa $\mathrm{Ha}$ ditolak. Artinya bahwa secara parsial variable X5 tidak memiliki pengaruh yang signifikan terhadap vaiabel Kinerja (Y).

\section{Pembahasan Hasil Penelitian} Pengaruh Organzational Citizenship Behavior terhadap kinerja dosen Universitas Sulawesi Barat. 
Hasil temuan dalam penelitian ini menunjukkan bahwa dari kelima indikator Organizational Citizenship Behavior yaitu altruism (X1), Conscientousness (X2), Civic Virtue (X3), Sportmanship (X4) dan Courtesy (X5) hanya variable $\mathrm{X} 1$ yang berpengaruh signifikan terhadap kinerja dosen Universitas Sulawesi Barat. Hal tersebut dapat dilihat dari hasil analisis atas pengujian pengaruh altruism terhadap kinerja pada table 34 menunjukkan bahwa nilai t hitung yang dihasilkan adalah 3,335 > t table 1,992 dan nilai koefisien regresi sebesar 0,274 dengan demikian altruisme (X1) berpengaruh signifikan terhadap kinerja dosen. Untuk variable $\mathrm{X} 2$, $\mathrm{t}$ hitung yang dihasilkan $1,026<\mathrm{t}$ table 1,992 berarti variable conscientiousness tidak berpengaruh signifikan terhadap kinerja dosen. Demikian juga untuk variable Civic Virtue (X3), $t$ hitung yang dihasilkan $-0,572<\mathrm{t}$ table 1,992, hal ini berarti variable X3 tidak berpengaruh terhadap kinerja dosen. Untuk variable Sportmanship nilai $\mathrm{t}$ hitung yang dihasilkan $-0,120<1,992$ hal ini juga menunjukkan bahwa tidak ada pengaruh antara variable $\mathrm{X} 4$ terhadap kinerja, sedangkan untuk variable Courtesy (X5) hasil uji regresi menunjukkan nilai $\mathrm{t}$ table $0,208<1,992$. Dari hasil tersebut diketahui bahwa variable X5 tidak berpengaruh signifikan terhadap kinerja dosen Universitas Sulawesi Barat.

\section{KESIMPULAN DAN SARAN}

Kesimpulan

1. Dalam penelitian ini terdapat enam variable yaitu lima variable $\mathrm{X}$ dan satu variable $\mathrm{Y}$ antara lain variable $\mathrm{X} 1$ (altruism) yaitu perilaku membantu meringankan pekerjaan yang ditujukan kepada individu dalam suatu organisasi,, variable X2 (Consceintiousness) yaitu melakukan hal-hal yang menguntungkan organisasi - seperti mematuhi peraturan peraturan di organisasi, variable X3 (Civic Virtue) yaitu terlibat dalam kegiatan kegiatan organisasi dan peduli pada kelangsungan hidup organisasi, selanjutnya variable X4 (Cortesy) yaitu membantu teman kerja mencegah timbulnya masalah sehubungan dengan pekerjannya dengan cara ber konsultasi dan informasi serta menghargai kebutuhan mereka,dan variable X5 (Sportmanship) yaitu toleransi pada situasi yang kurang ideal di tempat kerja tanpa mengeluh,

2. Responden dalam penelitian ini adalah dosen pada Universitas Sulawesi Barat yang terdiri dari 82 orang dengan penentuan sampel menggunakan metode slovin. Karakteristik responden terdiri dari laki-laki sebanyak 46 orang sedangkan perempuan sebanyak 36 orang. Karakteristik responden dari tingkat pendidikan yaitu S3 sebanyak 4 orang atau $7,31 \%, \mathrm{~S} 2$ sebanyak 78 orang atau sebanyak $85,41 \%$. Karakteristik responden dari segi usia, 26-30 tahun sebanyak 5 orang atau $6,09 \%$ selanjutnya usia antara 31-35 tahun sebanyak 38 orang atau $46,34 \%$, usia 36-40 tahun sebanyak 33 orang atau 40,20\% dan terakhir usia 41 45 tahun sebanyak 6 orang atau 7,31\%.

\section{Saran.}

Berdasarkan kesimpulan diatas, maka saran yang dapat diajukan dalam penelitian ini adalah : jika dilihat dari tingkat pendidikan dosen Universitas Sulawesi Barat masih banyak yang berpendidikan S2, sebaiknya Pimpinan Universitas lebih aktif dalam memotivasi para dosennya untuk meningkatkan pendidikannya ke jenjang S3. 


\section{DAFTAR PUSTAKA}

Ariani. D.W (2008) Perilaku Kewargaan Organisasional http/www. Ugm.ac.id/index php? Page $=$ rilis $\&$ artikel $=$ 112. Diakses tanggal 15 Juli 2009.

Balino M.C. Turnley, dan Bloodgood J.M. (2002) "Citizenship

Behavior and The Creation of Social Capital in

Organization”. Academy og Management Journal, Vol 7, No.4, 2002 PP. 502-522

Gomes F.C 1995. Manajemen Sumber Daya manusia. Andi offset, Yogyakarta

Nawawi, Hadari, 1991. Manajemen Sumber Daya Manusia, Gadjah Mada Press, Yogyakarta.

2003. Perencanaan SDM untuk Organisasi Profit yang Kompetitif, penerbit Gadjah Mada University Press, Yogyakarta.
Prawiro Sentono, 1999. Manajemen

Sumber Daya manusia,

Kebijakan Kinerja Karyawan, BPFE, Yogyakarta.

Podsakoff, P.M. Mackenzie, S.B. Paine. J. B; dan Bachrach, D.G (2000) "Organizational Citizenship Behavior; a critical Review of Theoritical Empirical Literature ang Sugestions for future Research" Journal of Management, 26 (3) : 513-563

Rivai, Veithzal \& Ahmad Fawzi Mohd Basri 2005. Performance Appraisal; Sistem yang tepat untuk Menilai Kinerja Karyawan dan Meningkatkan Daya perusahaan PT. Raja Grafindo Persada, Jakarta.

Simamora, Henry, 1997, Manajemen Sumber Daya Manusia, STIE YKPN Yogyakarta.

Wibowo, 2006. Manajemen

Perusahaan. PT. Gramedia

Pustaka Utama, Jakarta 